\title{
Case Study: Trends and Early Prediction of Rainfall in Jordan
}

\author{
Ali Ahmad Ghanem \\ The University of Jordan, Amman, Jordan \\ Email: aliahmad900@yahoo.com
}

Received October 16, 2012; revised November 15, 2012; accepted December 16, 2012

Copyright (C) 2013 Ali Ahmad Ghanem. This is an open access article distributed under the Creative Commons Attribution License, which permits unrestricted use, distribution, and reproduction in any medium, provided the original work is properly cited.

\begin{abstract}
Fourteen meteorological stations distributed over Jordan were selected. Data of annual and monthly rainfall amount of autumn (October and November) for a period more than 50 years were analyzed to show their relationships with the normal annual rainfall. An attempt was made to use the standard deviation values in order to have an early prediction for the annual rainfall (less or more than the normal) depending on the autumn rainfall amounts. It is found that the annual rainfall exceeded the normal when autumn rainfall amounts were more than $30 \mathrm{~mm}$ in Jurf El Daraweesh, Qatraneh, Safawi, and Wadi Musa, $50 \mathrm{~mm}$ in Mafraq, $60 \mathrm{~mm}$ in Amman, and $100 \mathrm{~mm}$ in Salt and Irbed. Regression analysis projected weak increasing trends in autumn and decreasing trends in the annual rainfall in the majority of Jordan.
\end{abstract}

Keywords: Rainfall; Standard Deviation; Relationship; Autumn; Jordan

\section{Introduction}

The rainy season in Jordan extends from October until May. A large part of Jordan is arid and semi-arid, about $90 \%$ of its area has an annual rainfall totally less than $200 \mathrm{~mm}$ on average, most of it evaporates back to the atmosphere. The arid climatic nature of the country makes rainfall more considerable, water resources mainly depend on rainfall, which is subjected to great variability [1-3]. Water availability in Jordan is one of the lowest in the world, the increasing population and human activities increase the shortage of water availability. Hence the amount of rainfall affects different sectors, such as agriculture, industry, health, domestic use, and so forth [4].

Due to the expected global warming, there is a universal concern about the variability of rainfall especially in the arid and semi-arid regions. Previous studies showed large variability of rainfall amounts in Jordan, they vary considerably from year to year $[3,5-7]$. There were many researchers analyzed rainfall data in different parts in the world about the surrounding regions such as analysis of rainfall data in the Kingdom of Saudi Arabia [8].

Interested scientists work on predicting annual rainfall amounts, such as the probability in Turkey [9], and in China [10], occurrence of dry and wet years, and also study the impacts on life aspects including agriculture [5, 11]. Therefore, the major impact of rainfall variability and water availability is the major concern in Jordan; this requires that policymakers should plan for future adaptation. Then understanding rainfall variability is essential for solving the water resources management problems associated with water availability. The objective of this paper is to analyze the relationships between the autumn rainfall (October and November) and the annual rainfall amounts, in order to have an early prediction of the annual rainfall, and to show the general rainfall trends during the studying period.

\section{The Study Area-Climate}

Jordan is located about $80 \mathrm{~km}$ to the east of the Mediterranean Sea, with an area of about $90,000 \mathrm{~km}^{2}$, and a population of 6.5 millions. Most of the rainfall amounts fall in winter months due to the impact of the Mediterranean Lows, weather of autumn and spring is affected also by the Red Sea and the Khamasin depressions.

Rainfall starts in autumn due to changes in the weather conditions as a result of changing the distribution of summer atmospheric pressure systems. This is summarized by the northward movement of the Siberian High and the westward movement of the Azores High, which puts the eastern region of the Mediterranean under the influence of the Red Sea Depressions as an extension of the Sudan-Low pressure [12]. The influence of the Mediterranean Lows (Midlatitude cyclones) starts later as they move southward in association with the Polar Jet 
stream [13-15]. Red Sea depressions cause atmospheric instability especially when combined with the existence of northwesterly cold winds in the upper atmosphere and easterly warm humid winds at the lower elevations. The Khamasin depressions move eastward across northern Africa to reach southwestern Asia. These depressions effects start in autumn more than any other season, causing rainfall over the areas surrounding the Red Sea which extends northward to include Jordan, Palestine, as well as northern Saudi Arabia $[12,13]$. The associated southerly winds cause the wide spread of the dust storms and the rise of temperature in Jordan mainly in southern and eastern parts [16].

\section{Data and Research Methodology}

To achieve the goal of this paper rainfall data of autumn months (October and November) and the annual rainfall amounts for fourteen stations were analyzed. Stations selected to represent all geographic and climatic regions in Jordan: desert, highlands and the Jordan Valley regions (Figure 1). In addition rainfall data were obtained for a long period starting from the beginning of the station to 2010 , it is more than 50 years, and it is long enough for climate studies. Therefore stations with short records and with missing data were excluded. Data were obtained from the Meteorological Department and the Ministry of Water in Jordan.

In this study, the averages and percentages of monthly and annual rainfall amounts were analyzed. The standard deviation values were used to find the relationships between autumn rainfall amounts and the annual rainfall.

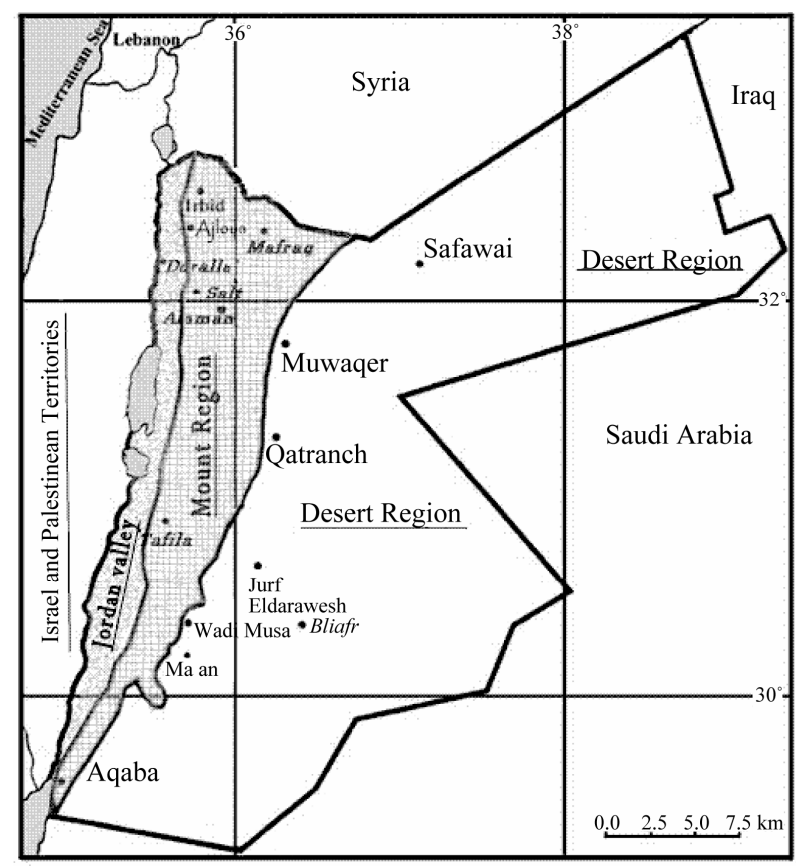

Figure 1. Distribution of stations over Jordan.
The standard deviation is better than the averages because the standard deviation shows the average squared deviation from the mean value, hence depicts the variability of the meteorological series. The standard devia-tion values show considerable differences between the geographic regions, and between wet and dry years. The standard deviations of the stations in the mountain region are smaller than in the desert and Jordan Valley regions. Regression analysis was applied to examine trends of rainfall for autumn and annually during the study period.

\section{Results and Discussion}

Table 1 shows the monthly average and standard deviation of rainfall amounts in autumn months for the studying stations. Data show large variation in rainfall amounts between desert and highlands stations and between southern and northern stations. It is clear that the standard deviations in autumn months are larger than the average because of the small number of rainy days, the number of rainy days were smaller than the number of the dry days. The high fluctuation in rainfall amount, spatially and temporally, in Jordan increases the difficultly for reaching comprehensive relationships between the monthly rainfall amounts in autumn and the annual rainfall amounts.

Krown $[11,17]$ examined the relationship between the amount of rainfall in October and the annual rainfall in Israel and found that the rainfall amounts less than (6 $\mathrm{mm})$ was followed by Rainfall higher than the annual average, and $(6-52 \mathrm{~mm})$ was followed by average rainfall amounts, and rainfall amounts more than $(100 \mathrm{~mm})$ followed by above-average rainfall. These relationships didn't apply correctly in Jordan. These relationships were not significant and their occurrences depend on chance, it was found that there was no relationship between low amounts of autumn rainfall and the annual rainfall amounts. This will be shown through reviewing the relationships between the amounts of rainfall in October and November with the annual rainfall amounts in Jordan.

\section{October Rainfall}

Rainfall of October is less than $5 \%$ of the average annual rainfall, ranging from $1 \%$ in Tafeleh station to $4.8 \%$ in Safawi Station. The beginning of the rainy season varies from one year to year and from one region to another. Shehadeh [18] found that the probability of the beginning of rainfall range from $39 \%$ for the first week of October to $87 \%$ for the fourth week. But these percentages do not apply to all stations because of the different rainfall characteristics of every geographic region in Jordan, the proportion of dry October (without rainfall) ranges from $(29 \%)$ in Ajloun to $(78 \%)$ in Aqaba. Percentages were 
Table 1. Mean and standard deviation (SD) for rainfall amounts in autumn (October and November) and the annual averages at the studying stations.

\begin{tabular}{ccccccccc}
\hline \multirow{2}{*}{ Station } & \multicolumn{2}{c}{ Annual } & \multicolumn{2}{c}{ Autumn } & \multicolumn{2}{c}{ November } & \multicolumn{2}{c}{ October } \\
\cline { 2 - 8 } & SD & Average & SD & Average & SD & Average & SD & Average \\
\hline Deir Alla & 105.2 & 281.1 & 49.1 & 46.1 & 47.4 & 38.3 & 9.7 & 8.7 \\
Maan & 23.5 & 41.3 & 6.4 & 5.1 & 4.7 & 3.7 & 3.2 & 1.9 \\
Aqaba & 24.3 & 32.6 & 7.1 & 4.1 & 6.5 & 3.3 & 3.2 & 0.8 \\
Tafeleh & 128.5 & 268.2 & 30.1 & 23.3 & 27.5 & 20.5 & 7.3 & 2.8 \\
Wadi Musa & 76.9 & 176.9 & 25.6 & 18.5 & 22.5 & 15.9 & 6.1 & 2.5 \\
Ajloun & 190.7 & 644 & 75.7 & 83.3 & 68 & 68 & 26.7 & 15.4 \\
Salt & 216.5 & 617.7 & 71.7 & 75.5 & 66.4 & 63.3 & 21.2 & 12.2 \\
Amman & 102.4 & 273.7 & 37.8 & 36.4 & 34 & 29.5 & 11.4 & 6.9 \\
Irbed & 159.3 & 414 & 50 & 59.5 & 45.9 & 47.9 & 19.4 & 11.6 \\
Safawi & 41.4 & 72.4 & 17.9 & 14.8 & 14.9 & 11.3 & 7.9 & 3.5 \\
Mafraq & 65.6 & 155.1 & 25.9 & 23 & 23.9 & 17.9 & 10.3 & 5.6 \\
Qatraneh & 39.4 & 95.6 & 12.2 & 9.8 & 10.3 & 7.5 & 5.1 & 2.3 \\
Muwaqer & 83.7 & 164.1 & 14.9 & 16.9 & 14.3 & 14.2 & 5.1 & 2.8 \\
Jurf Eldarawesh & 31.6 & 61.1 & 9 & 8.1 & 6.6 & 5.7 & 6.6 & 2.4 \\
\hline
\end{tabular}

great at stations located in the southern and eastern regions such as Wadi Musa 75\%, Jurf Eldaraweesh 72\%, Tafeleh 71\%, Muwaqer and Qatraneh 67\%; and decreases in the stations located in the northern and highlands regions to about 30\% in each of Irbed, Amman and Umm Qais.

From the analysis of monthly and annual rainfall data for the studied stations, the following relationships between the amounts of rainfall in October and the annual rainfall amounts were found:

1) There is no relationship between October rainfall and the annual rainfall in the years when the rainfall amounts of October were less than two standard deviations, for example the amounts less than $17 \mathrm{~mm}$ in Tafeleh, $29.7 \mathrm{~mm}$ in Amman, and $26.2 \mathrm{~mm}$ in Mafraq (Table 1). It is not permissible to use October rainfall that less than two standard deviations for predicting the annual rainfall amounts.

2) The annual rainfall amounts were more than the average in the majority of the studied stations in the years when October rainfall amounts were more than two standard deviations, with the exception of Jurf Eldaraweesh station where the annual rainfall was less than the average despite the high amount of rainfall in October.

3) The annual rainfall amounts were more than the average at all stations in the years when October rainfall amounts were more than three standard deviations, but the occurrence of these years were rare and their number ranged between $(0-3)$ years during the studied period.

Therefore, it is not easy to have an acceptable prediction of the annual rainfall amounts in the majority of the studied years when October rainfall was less than two standard deviations. The success rate of prediction increase as October rainfall exceeding two standard deviations, and approaching the accuracy of prediction of $100 \%$ was rare, which happened only when October rainfall amounts were more than three standard deviations. Table 2 shows autumn rainfall that followed by more than the average annual amounts. For example, the annual rainfall amounts were larger than average if October rainfall amounts were more than $22 \mathrm{~mm}$ in Jurf Eldarweesh, $70 \mathrm{~mm}$ in Ajloun, and $2 \mathrm{~mm}$ in Aqaba.

\section{November Rainfall}

November rainfall amounts is about $6 \%-15 \%$ of the average annual rainfall, the largest was $15 \%$ in Safawi and the least was $6.7 \%$ in Tafeleh, ratios in other stations were about $10 \%$. It is natural to attribute the larger rainfall amounts in November than in October to the increasing number of depressions that affect the country. It is important to mention that the Mediterranean cyclones influence may start before the end of November, which increases rainfall amounts.

November rainfall effect was not studied before as an indicator to predict the annual rainfall amounts. In spite of that the rainy season in many stations begins in November, when October is dry. Rainfall data analysis yields the following results:

1) Predicting the annual rainfall amounts depend on chance in years when November rainfall amounts were less than one standard deviation at all stations except Amman and Muwaqar (Table 1). For example the 
Table 2. Rainfall (mm) in autumn months that followedby rainfall more than the annual average.

\begin{tabular}{cccc}
\hline Station & October & November & Autumn \\
\hline Jurf Eldarawish & $>22$ & $>25$ & $>30$ \\
Ajloun & $>70$ & $>150$ & $>160$ \\
Qatraneh & $>20$ & $>20$ & $>30$ \\
Mafraq & $>25$ & $>30$ & $>50$ \\
Safawi & $>15$ & $>30$ & $>30$ \\
Wadi Musa & $>30$ & $>30$ & $>30$ \\
Salt & $>60$ & $>100$ & $>100$ \\
Um Qais & $>30$ & $>100$ & $>100$ \\
Irbed & $>40$ & $>100$ & $>100$ \\
Amman & $>30$ & $>40$ & $>60$ \\
Tafeleh & $>20$ & $>40$ & $>40$ \\
Aqaba & $>2$ & $>20$ & $>20$ \\
Deir Alla & - & $>50$ & $>60$ \\
\hline
\end{tabular}

amounts were $4 \mathrm{~mm}$ in Aqaba, $33.4 \mathrm{~mm}$ in Salt, $5.9 \mathrm{~mm}$ in Mafraq, and $31 \mathrm{~mm}$ in Irbed.

2) When November rainfall amounts were more than one standard deviation the annual rainfall amounts were more than the average at all stations except in Aqaba andJurf Elderaweesh.

3) Annual rainfall amounts were more than the average at all stations in the years when November rainfall amounts were more than two standard deviations.

It is noted that these relationships are different from the relationships already mentioned for October, and it can be said that the use of November rainfall is better than October rainfall to predict annual rainfall. The annual rainfall amount prediction would be acceptable in the cases when November rainfall amounts were over one standard deviation, and depend on the coincidence factor prediction if rainfall is less than that. For example, rainfall amounts were more than the average in the years that November rainfall amounts were more than $150 \mathrm{~mm}$ in Ajloun, $30 \mathrm{~mm}$ in Mafraq and Safawi, $100 \mathrm{~mm}$ in Umm Qais, Irbed, Salt, and $20 \mathrm{~mm}$ in Aqaba (Table 2).

\section{Autumn Rainfall}

Autumn rainfall amount (total rainfall of October and November) is about $15 \%$ of the annual average. Analysis of the data reveals that autumn rainfall amounts of less than one standard deviation were not suitable for predicting annual rainfall. In the years when autumn rainfall amounts were between one and two standard deviations the annual rainfall amounts were more than the average in the stations located in the northern highland region, such as Salt $(33.4 \mathrm{~mm}-45.6 \mathrm{~mm})$, Ajloun $(42.1 \mathrm{~mm}$ $57.5 \mathrm{~mm})$, Irbed (31 mm - $42.6 \mathrm{~mm})$, and Amman (18.3 $\mathrm{mm}-25.3 \mathrm{~mm}$ ). This relationship is uncertain in the sta- tions located in the southern and Eastern regions, such as Jurf Elderaweesh, Muwaqar, Qatraneh and Aqaba. The autumn rainfall in some years exceeded two standard deviations and the annual rainfall amounts were less than the average. This due to the important influence of the geographic location factor when judging the amount of annual rainfall; and because the southern and eastern regions are more affected by the khamasine and the Red Sea depressions in autumn, while the effect of Mediterranean Lows decreases.

It was observed that the annual rainfall amounts were more than the average at all stations in the years, when autumn rainfall amounts were more than three standard deviations. Table 3 shows the amounts of autumn rainfall that followed by more than the annual average were: $160 \mathrm{~mm}$ in Ajloun, $30 \mathrm{~mm}$ in Wadi Musa, $60 \mathrm{~mm}$ in Amman and Der Alla.

\section{Examples}

Jordan usually is affected by small number of depressions during autumn; it forms about $10 \%$ of the annual average of 28 depressions [18]. Table 3 shows the annual, October, November rainfall amounts in 1996, 2004, and 2008. It shows the following:

1) Rainfall amounts were less than the average in all stations except in 1996 in Safawi (99.2 mm), and Maan $(53 \mathrm{~mm})$, and in 2004 in Qatraneh $(123.7 \mathrm{~mm})$, Maan $60.2 \mathrm{~mm})$, and Irbed $(447.7 \mathrm{~mm})$.

2) October rainfall amounts were less than one standard deviation in all stations, except in Qatraneh in 2004 and 2008 .

3) November rainfall amounts were more than in October in most stations in 1996 and 2004. They were less than two standard deviations in all stations except in Safawi and Maan in 1996 and in Qatraneh and Irbed in 2004, where the annual amounts were more than the average. This confirms the relationship that the annual rainfall exceeds the average when November rainfall is more than two standard deviations.

4) October rainfall amounts in 2008 were more than in November, and annual rainfall amounts were less than the average. October rainfall in Qatraneh was more than two standard deviations; the annual rainfall was less than the average. This is an example of the uncertain relationship mentioned above.

5) All stations with autumn (October or November) rainfall less than two standard deviations had amounts less than the annual average, such as in Der Alla, Amman, Irbed, and Salt.

\section{Rainfall Trends}

Decreasing rainfall would have negative impacts on water availability, and then affects different social and eco- 
Table 3. Rainfall amounts (mm) of the 1996, 2004, 2007, and 2008.

\begin{tabular}{|c|c|c|c|c|c|c|c|c|c|}
\hline \multirow{2}{*}{ Station } & \multicolumn{3}{|c|}{1996} & \multicolumn{3}{|c|}{2004} & \multicolumn{3}{|c|}{2008} \\
\hline & Oct & Nov & Annual & Oct & Nov & Annual & Oct & Nov & Annual \\
\hline Qatraneh & 0.1 & 21.3 & 89.3 & 21.4 & 33.8 & $(123.7)$ & 16.6 & 0 & 74.6 \\
\hline Mafraq & 9.3 & 20.7 & 153.7 & 2.3 & 37.5 & 105.7 & 3.5 & 3 & 97.2 \\
\hline Safawi & 0 & 45 & $(99.2)$ & 3.5 & 11.8 & 49 & 10 & 0.6 & 47.4 \\
\hline Salt & 26.9 & 11.3 & 514.1 & 3.7 & 175.7 & 493.6 & 28.5 & 10.4 & 336.7 \\
\hline Maan & 0 & 21.6 & (53) & 4.1 & 0.8 & $(60.2)$ & 2.8 & 0 & 32.3 \\
\hline Irbed & 25 & 26.1 & 380.2 & 26 & 129.3 & $(447.7)$ & 6.1 & 11.6 & 300 \\
\hline Amman & 9.3 & 22.2 & 234.4 & 1.4 & 64.7 & 197 & 20.3 & 1.2 & 194.9 \\
\hline Der Alla & 14.2 & 7.7 & 274.2 & 8.4 & 94.5 & 245.8 & 16 & 5.3 & 166.5 \\
\hline
\end{tabular}

Table 4. Trend coefficients for the annual and autumn rainfall data. Significant at $95 \%$ level $\left({ }^{*}\right)$ and at $90 \%\left(^{* *}\right)$.

\begin{tabular}{|c|c|c|c|c|c|}
\hline Station & Annual trend & Autumn trend & station & Annual trend & Autumn trend \\
\hline Amman & $-0.52^{* *}$ & $0.51^{* *}$ & Deir Alla & $1.01^{*}$ & $0.64^{* *}$ \\
\hline Irbed & $1.15^{*}$ & $0.94^{*}$ & Maan & $-0.67^{* *}$ & $0.85^{*}$ \\
\hline Safawi & $-0.66^{* *}$ & $0.64^{*}$ & Aqaba & -0.15 & 0.11 \\
\hline Mafraq & 0.21 & $0.53^{* *}$ & Tafeleh & $-0.35^{* *}$ & 0.35 \\
\hline Qatraneh & -0.26 & $0.71^{*}$ & Wadi Musa & -0.29 & $0.56^{* *}$ \\
\hline Muwaqer & 0.31 & $0.60^{* *}$ & Ajloun & $1.4^{*}$ & $0.69^{*}$ \\
\hline Jurf Eldarawesh & $-0.98^{*}$ & $0.61^{* *}$ & Salt & $-0.54^{*}$ & $0.36^{* *}$ \\
\hline
\end{tabular}

nomic sectors. Therefore, scientists realize the importance of studying the trends and the early prediction of rainfall in Jordan. The simple regression analysis of rainfall data revealed an increasing trend in autumn-rainfall at all stations in the country, the trend coefficients range between 0.11 (low change) in Aqaba to 0.94 in Irbed (Table 4). For the annual rainfall, the analysis shows increasing trends in the northwestern part of the country (the coefficients were 1.15 in Irbed, 0.21 in Mafraq, 1.01 in Der Alla, and 1.4 in Ajloun), and decreasing trends in the rest of the country (the coefficients were -0.11 in Aqaba, -0.67 in Maan, -0.66 in Safawi, -0.52 in Amman, -0.54 in Salt, and -0.29 in Wadi Musa). Some of these results are weak and insignificant at $95 \%$ level of confidence. The increasing trends in autumn may cause future rainfall increase in Jordan. These results generally are in association with results of other researchers concerning rainfall trends in Jordan. Freiwan and Kadioglu [3] found a slight decreasing trend in rainfall, and Dahamsheh and Aksoy [7] found weak or no change in precipitation.

The rainfall decreasing trends were found in other surrounding regions, as in Greece [19], in Calabriain/Italy [20], in Crete [21], and a weak decreasing trend in Arabian Peninsula [22]. Researchers also found increasing trend in other regions around the Mediterranean.

\section{Conclusion}

The previous results indicate that the annual rainfall amounts at all stations were more than the annual average when rainfall amounts in October or November months were more than three standard deviations, extremely above the normal. The annual rainfall amounts were more than the average also in the years when the autumn rainfall amounts were more than two standard deviations. The rainfall amounts in October or November of less than two standard deviations are not suitable for predicting annual rainfall. The success rate of prediction varies from one station to another according to their geographical location. As a result of the different direction and strength of the relationship between the autumn rainfall and the annual rainfall, there is no linear relationship could rely upon to predict the annual rainfall. There were increasing trends in autumn rainfall. In the annual rainfall there were increasing trends in the northwest part of the country, and decreasing trends in the rest of the country.

\section{REFERENCES}

[1] A. Ghanem, "Trends in mean seasonal and annual rainfall amounts over Jordan," Dirasat, University of Jordan, Vol. 8, 2011, pp. 1041-1049. 
[2] A. Ghanem, "Analysis of Decadal Rainfall in Jordan. Dirasat, Natural and Engineering Sciences," University of Jordan, 1997, pp. 179-201.

[3] M. Freiwan and M. Kadioglu, "Climate Variability in Jordan," International Journal of Climatology, Vol. 28, No.1, 2008, pp. 69-89. doi:10.1002/joc. 1512

[4] S. A. Talozi Samer, "Water and Security in Jordan," In: C. Lipchin, Ed., Integrated Water Resources Management and Security in the Middle East, Springer, 2007, pp. 73-98. doi:10.1007/978-1-4020-5986-5_4

[5] A. Ghanem, "Analysis of Aridity Index for the Rainy Season in Jordan," Tunisian Journal of Geography, Vol. 28, 1995, pp.79-67.

[6] Q. Tarawneh and M. Kadioglu, "An Analysis of Precipitation Climatology in Jordan," Theoretical and Applied Climatology, Vol. 71, No. 1-2, 2003, pp.71-85.

[7] A. Dahamsheh and H. Aksoy, "Structural Characteristics of Annual Precipitation Data in Jordan," Theoretical and Applied Climatology, Vol. 88, No. 3-4, 2007, pp. 201-212. doi:10.1007/s00704-006-0247-3

[8] A. M. Subyani, "Geostatistical Study on Annual and Seasonal Rainfall Patterns in Southwest Saudi Arabia," $\mathrm{Hy}$ drological Sciences Journal, Vol. 49, No. 5, 2004, pp. 803-817.

[9] M. Kadioglu, N. Ozturk, H. Erdun and Z. Sen, "On the Precipitation Climatology of Turkey by Harmonic Analysis," International Journal of Climatology, Vol. 19, 1999, pp. 1717-1728. doi:10.1002/(SICI)1097-0088(199912)19:15<1717::AIDJOC470>3.0.CO;2-\#

[10] M. Gemmer, S. Becker and T. Tiag, "Observed Monthly Precipitation Trends in China 1951-2002," Theoretical and Applied Climatology, Vol. 77, No. 1-2, 2004, pp. 3945. doi:10.1007/s00704-003-0018-3

[11] L. Krown, "An Approach to Forecasting Seasonal Rainfall in Israel," Journal of Applied Meteorology, Vol. 5, No. 5, 1966, pp. 590-594. doi:10.1175/1520-0450(1966)005<0590:AATFSR $>2.0 . C$ $\underline{\mathrm{O} ; 2}$
[12] M. A. Toum, "Sudan Climate," Nafe' Printing House, Cairo, 1974.

[13] M. Hatzaki, H. A. Flocas, H. D. N. Asimakopoulos and R. Maheras, "The Eastern Mediterranean Teleconnection Pattern: Identification and Definition," International Journal of Climatology, Vol. 27, No. 6, 2007, pp.727-737. doi:10.1002/joc. 1429

[14] P. A. Kassomenos, "Anatomy of the Synaptic Conditions Occurring over Southern Greece during the Second Half of the 20th Century," Theoretical and Applied Climatology, Vol. 75, 2003, pp. 65-77.

[15] U. Dayan and A. Richard, "Heavy Rain in the Middle East Related to Unusual Jet Stream Properties," Bulletin of the American Meteorological Society, Vol. 64, No. 10, 1983, pp. 1138-1140.

[16] Y. Khalil, "Sand-Dust Storms in Jordan (1975-200500)," Ph.D. Dissertation, Jordan University, Amman, 2008.

[17] L. Krown, "Notes in October Rainfall as an Indication of Seasonal Rainfall Expectation for Israel," Israel Meteorological Service, 1951, $10 \mathrm{p}$.

[18] N. Shehadeh, "Jordan Climate," Dar Al-Bashir, Amman, 1990.

[19] L. Kioutsioukis, D. Melas and C. Zerefos, "Statistical Assessment of Changes in Climate Extremes over Greece (1955-2002)," International Journal of Climatology, Vol. 3, No. 11, 2010, pp. 1723-1737. doi:10.1002/joc.2030

[20] T. Caloiero and R. Coscarell, E. Ferrari and M. Mancini, "Trend Detection of Annual and Seasonal Rainfall in Calabria (Southern Italy)," International Journal of Climatology, Vol. 31 No. 1, 2011, pp. 44-56. doi:10.1002/joc. 2055

[21] S. Naoum and I. Tsanis, "Temporal and Spatial Variation of Annual Rainfall on the Island of Crete, Greece," $\mathrm{Hy}$ drological Processes, Vol. 17, No. 10, 2003, pp. 1899 1922. doi:10.1002/hyp. 1217

[22] H. A. Nasrallah and A. C. Balling, "Analysis of Recent Climatic Changes in the Arabian Peninsula Region," Theoretical and Applied Climatology, Vol. 53, No. 4, 1996, pp. 245-252. doi:10.1007/BF00871740 